\title{
Features of growth and development of Scutellaria baicalensis Georgi under conditions of introduction in the Middle Urals
}

\author{
A. V. Abramchuk ${ }^{1}$, M. Yu. Karpukhin ${ }^{1 \bowtie}$, S. E. Saparklycheva ${ }^{1}$, V. V. Chulkova ${ }^{1}$ \\ ${ }^{1}$ Ural State Agrarian University, Ekaterinburg, Russia \\ ${ }^{凶}$ E-mail: mkarpukhin@yandex.ru
}

Abstract. An experiment on the topic "Features of the growth and development of Scutellaria baicalensis Georgi under conditions of introduction in the Middle Urals" was carried out at the educational farm "Uralets". Purpose of the study: to study the influence of the feeding area on the growth and development of Scutellaria baicalensis Georgi. The objectives of the study were to study the influence of the feeding area on: the dynamics of height and average daily growth, dates of the onset and timing of phenological phases, biometric indicators of leaves and inflorescences, structural composition of aboveground biomass, productivity of aboveground and underground biomass. Research methods. The experiment scheme includes 3 options: 1 variant $-33 \times 30 \mathrm{~cm}\left(990 \mathrm{~cm}^{2}\right)-$ control; 2 variant $-33 \times$ $45 \mathrm{~cm}\left(1485 \mathrm{~cm}^{2}\right) ; 3$ variant $-33 \times 60 \mathrm{~cm}\left(1980 \mathrm{~cm}^{2}\right)$. Results. It was found that an increase in the feeding area enhances the differentiation of plants in terms of the rate of passage of phenological phases. The earliest transition to the generative stage of development was noted in variants II and III (24.06). The maximum average daily gain was observed in the II and III decades of July, according to the variants it varied from 0.78 ( $1^{\text {st }}$ stage) to $1.22 \mathrm{~cm} /$ day (III stage). The highest biological productivity was obtained in variant 3 with a feeding area of $33 \times 60 \mathrm{~cm}$; on average, it reached $251.5 \mathrm{~g}$ per plant, which is $162.2 \mathrm{~g}(181.6 \%)$ higher than in the control. Scientific novelty. For the first time, there was studied, the influence of the feeding area on the most important aspects of the growth and development of Scutellaria baicalensis Georgi in the conditions of the Middle Urals. The optimal feeding area $\left(1980 \mathrm{~cm}^{2}\right)$ has been established, at which the Scutellaria baicalensis Georgi is able to form a fairly high productivity.

Keywords: Scutellaria baicalensis Georgi, phenological phases, aboveground biomass, structural composition, productivity.

For citation: Abramchuk A. V., Karpukhin M. Yu., Saparklycheva S. E., Chulkova V. V. Features of the growth and development Georgi under conditions of introduction in the Middle Urals // Agrarian Bulletin of the Urals. 2021. No. 05 (208). Pp. 2-7. DOI: 10.32417/1997-4868-2021-208-05-2-7.

Date of paper submission: 01.04.2021, date of review: 08.04.2021, date of acceptance: 26.04.2021.

\section{Introduction}

Constant uncontrolled anthropogenic loads on natural landscapes, unsystematic collection of medicinal wildgrowing raw materials, as well as the high demand of the pharmaceutical industry for plant raw materials are the most important factors that lead to a rapid decline in natural populations of many medicinal plants $[1, \mathrm{p} .8]$, [2, p. 11], [3, p. 15]. Scutellaria baicalensis Georgi belongs to rare and endangered plants, for the preservation of which it is necessary to introduce it into culture $[4$, p. 11], [5, p. 179].

Scutellaria baicalensis Georgi belongs to the Lamiaceae family, is a relict plant of the Tertiary period, it is included in the category of endangered species [1, p. 177], [5, p. 179]. In the Eastern Transbaikalia, the species is confined to the richly herb real and meadow steppes, the southern slopes of the forest-steppe belt; in the Amur region, Primorye, in the Far East - to the steppes [6, p. 223], [7, p. 90]. Ecologically, the plant belongs to the group of cryomesoxerophytes, occupies open forest-steppe and steppe areas, and is widespread on stony-gravelly soils $[7$, p. 91], [8, p. 151].

The pharmacological effectiveness of Scutellaria baicalensis Georgi is due to the content of a wide range of biologically active compounds, such as: flavonoids, coumarins, tannins, essential oils. Scutellaria flavonoids have a hypotensive, sedative, tonic, antispasmodic, anticonvulsant effect; have anti-inflammatory, tonic, anti-allergenic action; Scutellaria preparations exhibit P-vitamin activity $[13$, p. 147]. Powerful antioxidant properties are effective in the treatment of patients with cancer [9, p. 128], [10, p. 61], [13, p. 147]. Scutellaria baicalensis Georgi has a pronounced antiviral activity, especially against the influenza virus, it stimulates the synthesis of endogenous interferon [14, p. 120]. Flavones, amino acids, steroids, essential oils were isolated from the roots of Scutellaria baicalensis Georgi [4, p. 62], [1, pp. 177-178]. To date, 125 phenolic compounds with various structures have 
been found in the plant $[9$, p. 130], [10, p. 61]. The main biologically active substances contained in the root systems of skullcap include: baicalin is a unique plant compound that exhibits: antiviral, anti-hypertensive, antiinflammatory and antitumor activity; wogonin helps to stabilize the condition in case of nervous disorders; scutellarin weakens the excitability of the nervous system; enhances heart contractions, slows the heart rate, lowers blood pressure [15, p. 244].

Scutellaria preparations are of little toxicity. In scientific medicine, they are used as an antihypertensive and sedative for various forms of hypertension, functional disorders of the nervous system, and cardiovascular diseases.

Baikal skullcap has long been used in Chinese, Tibetan, Japanese medicine as a tonic, sedative and antipyretic agent. The works of Japanese scientists have established antithrombotic, anti-allergenic, anti-asthmatic action. The Baikal skullcap regulates the level of leukocytes in the blood, inhibits the formation of metastases; is adaptogenic, increases the body's resistance to infectious diseases $[1$, p. 178]. Recently it has been intensively studied in our scientific medicine.

\section{Methods}

Research was carried out in the educational farm "Uralets", located in the Beloyarsk district, Sverdlovsk region, at the collection site of medicinal plants of the Ural state agrarian university. The soil is podzolized heavy loamy chernozem. The reaction of the soil medium is slightly acidic ( $\mathrm{pH}$ salt. extract 5.5); humus content $7.1 \%$, cation exchange capacity $-32-35 \mathrm{mmol} / 100 \mathrm{~g}$; the sum of exchangeable bases is $27-30 \mathrm{mmol} / 100 \mathrm{~g}$. Black fallow was used as a precursor; in the fall of 2017, deep tillage was carried out (autumn plowing to a depth of $25-27 \mathrm{~cm}$ ), followed by cultivation and harrowing. In the experiment we used the seedling method of cultivating the Baikal skullcap. Substrate for sowing seeds - nutritious soil, universal FASCO "Ogorodnik". Soil composition: high-moor peat, low peat, sand, limestone (dolomite) flour, complex mineral fertilizer; content of nutrients available to plants $(\mathrm{mg} / \mathrm{kg})$, not less than $\mathrm{N} 250, \mathrm{P}_{2} \mathrm{O}_{5} 400, \mathrm{~K}_{2} \mathrm{O} 500 ; \mathrm{pH}$ 7. Seed germination was 60-65\%. Sowing for seedlings was carried out on April 10, 2018. Planting seedlings in open ground - on May 10, 2018; seedling height at planting varied from 5.7 to $6.9 \mathrm{~cm}$, on average $-6.2 \mathrm{~cm}$.

The experimental scheme included 3 options that differed in feeding area: Option $1-33 \times 30 \mathrm{~cm}\left(990 \mathrm{~cm}^{2}\right)-$ control; option $2-33 \times 45 \mathrm{~cm}\left(1485 \mathrm{~cm}^{2}\right)$; option $3-$ $33 \times 60 \mathrm{~cm}\left(1980 \mathrm{~cm}^{2}\right)$. Plot area is $3 \mathrm{~m}^{2}$, replication three times. During the growing season there were carried out two weeding and 2-3 cultivation. All records and observations were done according to generally accepted methods, mathematical processing of the results obtained - according to B. A. Dospekhov [11, pp. 271-289].

Study of the influence of the feeding area on the dynamics of height and average daily growth, dates of the onset and timing of phenological phases, biometric indicators of leaves and inflorescences, structural composition of aboveground biomass, productivity of aboveground and underground biomass. Height measurements were carried out on marked individuals, regularly, once a week; biometric indicators of leaves and inflorescences, structural composition and productivity of aboveground biomass were determined during the harvesting period (first decade of August). Determination of the underground biomass' productivity - at the end of September, in all variants simultaneously, when the plants have finished the growing season. The root system was dug up, cleaned of soil, then washed from soil particles, removed excess moisture with filter paper, laid out for drying for 2 days, then the roots were weighed on an electronic balance.

\section{Results}

Baikal skullcap (Scutellaria baicalensis Georgi) is a plant of the forest-steppe and steppe landscapes of Transbaikalia. Ecologically and phytocenotically associated with the formation of the filamentous steppe, widespread in Eastern Transbaikalia. The climatic conditions of the Middle Urals are quite significantly different from the conditions of Transbaikalia in such factors as: the sum of positive temperatures, moisture, the duration of the growing season, which have a great influence on the growth and development of Scutellaria baicalensis. According to its biological characteristics, it belongs to perennial herbaceous plants, the height of generative shoots ranges from 20 to $70 \mathrm{~cm}$.

In the course of the study, the dynamics of the height of Scutellaria baicalensis was monitored. A slower regrowth of plants during the entire growing season was noted in the first option, with a nutritional area of $33 \mathrm{x}$ $30 \mathrm{~cm}$. In the period of determining the productivity of aboveground biomass, the maximum plant height was noted in the third option: $39 \mathrm{~cm}$ (2018), $53 \mathrm{~cm}$ (2019), $58 \mathrm{~cm}$ (2020). Intensive growth of the aboveground biomass, over the years of the study, was observed in the third variant - 0.9-1.22 cm per day. In general, in the development of Scutellaria baicalensis plants, the maximum of the average daily growth is well pronounced - In the $2^{\text {nd }}$ $3^{\text {rd }}$ decade of July, when its value varied in variants from 0.78 to $1.22 \mathrm{~cm}$ per day. It was during this period that active regrowth of the aboveground part of plants was observed in all studied variants. An analysis of the dynamics of height and average daily gain showed that the growth and development of Scutellaria baicalensis plants largely depend on the feeding area: the larger the feeding area, the better the plants are developed. At the same time, the complex of natural and climatic conditions also has a noticeable effect, first of all - the temperature regime and the degree of moisture. Low positive temperatures $\left(+9 \ldots 12^{\circ} \mathrm{C}\right)$ had a negative effect, slowing down all the growth processes of Scutellaria baicalensis Georgi.

In the course of the experiment, it was found that an increase in the feeding area enhances the differentiation of plants according to the rates of passage of phenological phases (table 1). The earliest transition to the generative stage of development (budding phase) was noted in variants II and III (24.06); the phase of mass flowering began earlier than everyone else in option III (10.07), much later - in option 1 (21.07), the difference between options 1 and III was 11 days.

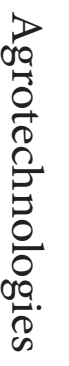


Аграрный вестник Урала № 05 (208), 2021 г.

Phenological features of the Scutellaria baicalensis Georgi, 2019

\begin{tabular}{|c|c|c|c|c|c|c|}
\hline \multirow{3}{*}{$\begin{array}{c}\text { The variants } \\
\text { of the experiment } \\
\text { (feeding area, } \mathrm{cm} \text { ) }\end{array}$} & \multicolumn{6}{|c|}{ Dates of occurrence of phenological phases } \\
\hline & \multirow{2}{*}{$\begin{array}{c}\text { The beginning } \\
\text { of regrowth }\end{array}$} & \multirow{2}{*}{ Budding } & \multicolumn{2}{|c|}{ Flowering } & \multicolumn{2}{|c|}{ Fruiting } \\
\hline & & & Beginning & Mass & Beginning & Mass \\
\hline I option $-33 \times 30$ (control) & 10.05 & 28.06 & 11.07 & 21.07 & 14.08 & 19.09 \\
\hline II option $-33 \times 45$ & 10.05 & 24.06 & 4.07 & 13.07 & 5.08 & 14.09 \\
\hline III option $-33 \times 60$ & 10.05 & 24.06 & 3.07 & 10.07 & 2.08 & 10.09 \\
\hline
\end{tabular}

Table 2

The period spent by plants of the Scutellaria baicalensis Georgi, from the beginning of regrowth to the onset of phenological phases, 2019

\begin{tabular}{||c|c|c|c|c|c|}
\hline \multirow{2}{*}{$\begin{array}{c}\text { The variants } \\
\text { of the experiment } \\
\text { (feeding area, cm) }\end{array}$} & \multicolumn{2}{|c|}{ The period from regrowth to the onset of phenological phases (days) } \\
\cline { 2 - 6 } & \multirow{2}{*}{ Budding } & \multicolumn{2}{|c|}{ Flowering } & \multicolumn{2}{c|}{ Fruiting } \\
\cline { 2 - 6 } & & Beginning & Mass & Beginning & Mass \\
\hline I option $-33 \times 30($ control) & $50 \pm 3.12$ & $63 \pm 4.17$ & $73 \pm 3.32$ & $97 \pm 3.57$ & $133 \pm 4.32$ \\
\hline II option $-33 \times 45$ & $46 \pm 2.74$ & $56 \pm 3.09$ & $65 \pm 2.86$ & $88 \pm 2.30$ & $128 \pm 2.11$ \\
\hline III option $-33 \times 60$ & $46 \pm 2.39$ & $55 \pm 1.93$ & $63 \pm 2.05$ & $85 \pm 2.01$ & $124 \pm 1.98$ \\
\hline
\end{tabular}

Table 3

Biometric features of leaves and inflorescences of Scutellaria baicalensis Georgi (average per 1 generative shoot, for 2018-2019)

\begin{tabular}{|c|c|c|c|c|c|}
\hline \multirow{2}{*}{$\begin{array}{c}\text { The variants } \\
\text { of the experiment } \\
\text { (feeding area, } \mathrm{cm} \text { ) }\end{array}$} & \multicolumn{3}{|c|}{ Leaves } & \multicolumn{2}{|c|}{ Inflorescence } \\
\hline & $\begin{array}{l}\text { Number of } \\
\text { leaves, pcs. }\end{array}$ & Length, cm & Width, cm & $\begin{array}{l}\text { Number of } \\
\text { flowers, pcs. }\end{array}$ & Length, $\mathrm{cm}$ \\
\hline I option $-33 \times 30$ (control) & 17.6 & 3.9 & 0.59 & 9.2 & 13.8 \\
\hline II option $-33 \times 45$ & 20.3 & 4.8 & 0.72 & 10.6 & 14.7 \\
\hline III option $-33 \times 60$ & 20.6 & 4.9 & 0.78 & 11.2 & 15.4 \\
\hline
\end{tabular}

The feeding area had a significant effect on the period that the plants spent from the beginning of regrowth to the onset of phenological phases (table 2). In general, Scutellaria baicalensis is characterized by a prolonged flowering period, mass flowering was observed in the $2^{\text {nd }}$ decade of July, 63-73 days after regrowth; some individuals continued to bloom until the end of September (before the onset of frost). The phase of mass fruiting was noted in the control variant after 133 days, much earlier in variant III, after 124 days, which is of great importance for the growth and development of plants, especially for the formation of seeds, in the climatic conditions of the Middle Urals.

It should be noted that the transition of plants to mass fruiting occurred rather late, in the second decade of September. As a result of the acropetal sequence of blooming flowers in the inflorescence (development proceeded from the base to the top), by the end of the growing season, mature seeds were formed in the lower part of the inflorescence, in the middle - immature (greenish-brown capsules), and in a number of individuals in the upper part of the inflorescence there was observed the end of flowering. In general, under the conditions of the Middle Urals, Scutellaria baicalensis Georgi undergoes a full development cycle during the growing season: the transition to the generative stage was noted at the end of June, the flowering phase began in the 2nd and 3rd decades of July, the phase of the beginning of fruiting - in the $1^{\text {st }}-2^{\text {nd }}$ decades of August, mass fruiting - in the $1^{\text {st }-2^{\text {nd }}}$ decades of September. Self-seeding was observed from the second year of development.
In the course of the study, the influence of the feeding area on the biometric parameters of leaves and inflorescences of Scutellaria baicalensis was studied (table 3). In the control variant, the number of leaves varied from 14.5 to 26.5 pieces, on average -17.6 pieces. leaves per generative shoot. The length and width of the leaves averaged $3.9 \mathrm{~cm}$ and $0.59 \mathrm{~cm}$, respectively. Low rates are also characteristic of inflorescences: the length varied from 12.2 to $15.1 \mathrm{~cm}$, on average $-13.8 \mathrm{~cm}$, which is 0.9 and $1.6 \mathrm{~cm}$ less than in variants 2 and 3 . The number of flowers on the generative shoot is significantly lower. The best biometric characteristics of leaves and inflorescences were obtained in variants II and III.

In the aboveground biomass of Scutellaria baicalensis, an increased content of biologically active substances is noted. The main flavonoid components of the aerial part are luteolin, apigenin [9, p. 129], [10, p. 61]. Luteolin has antioxidant, anti-inflammatory, anti-allergic, antitumor and immunomodulatory effects [9, p. 130]. Luteolin is a powerful hypoglycemic agent - it increases insulin sensitivity. Apigenin has anti-inflammatory, antioxidant and anticancer properties. In addition, the aerial part is distinguished by a significant content of carotenoids [13, p. 147]. The greatest accumulation of biologically active compounds in the plant material of Scutellaria baikalis is observed in the phase of mass flowering $[9$, p. 130]. The use of aboveground mass as a medicinal raw material, in contrast to root systems, the procurement of which undermines the reproduction of the species for many years, will reduce the negative anthropogenic impact on the populations of Scutellaria baicalensis Georgi, slow down their degradation [1, p. 177], [12, p. 24]. 
Biological productivity of aboveground biomass of the Scutellaria baicalensis Georgi (average for the 2018-2020)

\begin{tabular}{|c|c|c|c|c|c|c|}
\hline \multirow{3}{*}{$\begin{array}{c}\text { The variants of the } \\
\text { experiment (feeding area, } \mathrm{cm} \text { ) }\end{array}$} & \multicolumn{6}{|c|}{ Aboveground biomass } \\
\hline & \multirow[t]{2}{*}{ Productivity, g/plant } & \multicolumn{2}{|c|}{$\begin{array}{c}\text { Deviation from } \\
\text { control }(+)\end{array}$} & \multirow[t]{2}{*}{ Productivity, $\mathrm{g} / \mathrm{m}^{2}$} & \multicolumn{2}{|c|}{$\begin{array}{l}\text { Deviation from } \\
\text { control }(+)\end{array}$} \\
\hline & & $g$ & $\%$ & & $g$ & $\%$ \\
\hline I option $-33 \times 30$ (control) & 89.3 & - & - & 893.2 & - & - \\
\hline II option $-33 \times 45$ & 176.1 & 86.8 & 97.2 & 1232.7 & 339.5 & 38.0 \\
\hline III option $-33 \times 60$ & 251.5 & 162.2 & 181.6 & 1257.5 & 364.2 & 40.8 \\
\hline $\begin{array}{l}L S D_{05}: \\
2018 \\
2019 \\
2020\end{array}$ & $\begin{array}{l}10.7 \\
13.9 \\
17.3\end{array}$ & & & $\begin{array}{l}49.6 \\
57.4 \\
60.1\end{array}$ & & \\
\hline
\end{tabular}

In the study, the biological productivity of the aboveground biomass was determined in the first decade of $\mathrm{Au}$ gust. Shoots were cut at a height of 5-7 cm from the soil surface, weighed in the laboratory, and the green mass was obtained from one plant. The results obtained in the experiment are shown in table 4, from which it can be seen that the productivity of the aboveground biomass of Scutellaria baicalensis largely depends on the feeding area. During the three years of the study (2018-2020), a rather low biological productivity was formed by skullcap in the control variant, where the feeding area is the smallest $(33 \times 30 \mathrm{~cm})$; on average, over 3 years of observation, it was $89.3 \mathrm{~g} /$ plant. With an increase in the feeding area to $33 \times 45 \mathrm{~cm}$, productivity increases significantly, the increase in comparison with the control was $86.8 \mathrm{~g}$ $(97.2 \%)$. In the third variant, with a feeding area of $33 \times$ $60 \mathrm{~cm}$, the biological productivity, on average per plant, reached $251.5 \mathrm{~g}$, which is $162.2 \mathrm{~g}(181.6 \%)$ more than in the control. The yield per unit area increased significantly, it amounted to $1257.4 \mathrm{~g} / \mathrm{m}^{2}$ - this is the maximum value of the aboveground biomass obtained in the experiment. Over the years of the study, the differences in the value of the aboveground biomass between options 2 and 3 decreased, and in 2020 they are within the experimental error.

When harvesting aboveground biomass used as a medicinal raw material, its structural composition is of great importance, on which the medicinal properties of plants depend. It is known that in the structure of the aboveground biomass, the most valuable two fractions - leaves and inflorescences, in which the highest content of biologically active substances is noted, is much lower - in the shoots.

The structural composition of the aboveground biomass in the experiment was determined during the harvesting period (the first decade of August), at this time the plants were in two phases of generative development: mass flowering and the beginning of fruiting. From the data presented in table. 5 it can be seen that the plants, in the studied variants, differ quite significantly in their structural composition. Significant differences were observed in the formation of the fruits' mass: $1^{\text {st }}$ variant (control) - $4.6 \mathrm{~g} ; 2^{\text {nd }}$ variant $-12.5 \mathrm{~g} ; 3^{\text {rd }}$ variant $-18 \mathrm{~g}$.

The best results were obtained with an increase in the feeding area to $33 \times 60 \mathrm{~cm}$, the weight of all structural elements increased significantly: the proportion of leaves was $100.1 \mathrm{~g}$; flowers $-41.2 \mathrm{~g}$; fruits $-18.1 \mathrm{~g}$; shoots of different orders $-92.1 \mathrm{~g} / \mathrm{plant}$, which is significantly higher than in other variants.

All parts of plants - roots, stems, leaves, inflorescences and flowers - have a certain set of medicinal substances, but the concentration of compounds useful for use in different parts of plants is different [2, p. 7]. In Scutellaria baicalensis, the highest content of biologically active substances is noted in the root systems, which are most often used to obtain medicinal products [12, p. 24]. They contain flavonoids: baicalin, baicalein and wogonin (up to $4.5 \%$ ). In addition, the roots found: glycoside scutellarin, steroid saponins, essential oil, resins, tannins, up to $2.5 \%$ pyrocatechins. The ash of the roots contains: macroelements $(\mathrm{mg} / \mathrm{g}): \mathrm{K}-10.6 ; \mathrm{Ca}-4.4 ; \mathrm{Mg}-8.4$; $\mathrm{Fe}-0.6$; trace elements $(\mu \mathrm{g} / \mathrm{g}): \mathrm{Cu}-0.88 ; \mathrm{Se}-0.95 ; \mathrm{Sr}-$ $0.51 ; \mathrm{Mn}-0.17 ; \mathrm{Al}-0.43 ; \mathrm{Pb}-0.1$; concentrates Fe, Mo, Se [1, p. 177], [6, p. 223].

Morpho-biological indicators of the root systems of Scutellaria baicalensis were determined in late September-early October 2018-2020. (at the end of the growing season of plants). A close relationship was revealed between the feeding area and the productivity of the skullcap root systems: an increase in the feeding area has a positive effect on all morpho-biological characteristics of the underground organs of Scutellaria baicalensis [12, p. 25]. According to the years of the study, the lowest indicators were observed in the control variant, where the parameters of the root systems: length, diameter, number of lateral tap roots of the $1^{\text {st }}$ order and the size of caudex were significantly inferior to the other two studied variants.

The best results were provided by the third option: the root system is maximally developed; the caudex is well pronounced, the length of which is $1.5 \mathrm{~cm}$ longer than in the control variant. Significant differences are also observed in the number of lateral taproots: in option I $(33 \times 30)$ there are 4.5 of them, while in option III $(33 \times 60)-11.5$, which is 1.6 times more than in control. The highest productivity of underground biomass was also obtained in variant III: on average, it reached $51.8 \mathrm{~g} /$ plant per plant, which is $32.1 \mathrm{~g}(162.9 \%)$ more than in the control variant and by $15.9 \mathrm{~g}(80.7 \%)$ is higher than in option II. 
Аграрный вестник Урала № 05 (208), 2021 г.

Table 5

Structural composition of aboveground biomass of Scutellaria baicalensis Georgi

(average per plant for 2018-2020)

\begin{tabular}{|c|c|c|c|c|c|c|c|c|}
\hline \multirow{3}{*}{$\begin{array}{l}\text { The variants of the } \\
\text { experiment (feeding area, } \mathrm{cm} \text { ) }\end{array}$} & \multicolumn{8}{|c|}{ Structure of aboveground biomass } \\
\hline & \multicolumn{2}{|c|}{ Leaves } & \multicolumn{2}{|c|}{ Flowers } & \multicolumn{2}{|c|}{ Fruits } & \multicolumn{2}{|c|}{ Shoots of different orders } \\
\hline & $g$ & $\%$ & \multirow{2}{*}{$\frac{g}{15.3}$} & $\%$ & $g$ & $\%$ & $g$ & $\%$ \\
\hline \multirow{2}{*}{\begin{tabular}{|l|} 
I option $-33 \times 30($ control $)$ \\
II option $-33 \times 45$
\end{tabular}} & 33.0 & 37.0 & & 17.1 & 4.6 & 5.2 & 36.4 & 40.7 \\
\hline & 67.4 & 38.3 & \multirow{2}{*}{$\frac{31.0}{41.2}$} & 17.6 & 12.5 & 7.1 & 65.2 & 37.0 \\
\hline III option $-33 \times 60$ & 100.1 & 39.8 & & 16.4 & 18.1 & 7.2 & 92.1 & 36.6 \\
\hline \multicolumn{9}{|c|}{$\begin{array}{r}\text { Table } 6 \\
\text { Morpho-biological features of root systems Scutellaria baicalensis Georgi (average per plant for 2018-2020) }\end{array}$} \\
\hline \multirow{3}{*}{$\begin{array}{c}\text { The variants } \\
\text { of the experiment } \\
\text { (feeding area, } \mathrm{cm})\end{array}$} & \multicolumn{7}{|c|}{ Underground organs } & \multirow{3}{*}{$\begin{array}{c}\text { Weight of } \\
\text { underground } \\
\text { organs, } g\end{array}$} \\
\hline & \multicolumn{3}{|c|}{ Caudex, $\mathrm{cm}$} & \multicolumn{4}{|c|}{ Lateral tap roots } & \\
\hline & Length & Diamete & & ength, cm & Diamete & $\mathrm{cm}$ & Number, pcs. & \\
\hline I option $-33 \times 30$ (control) & 1.35 & 1.1 & & 18.6 & 0.37 & & 4.5 & 19.7 \\
\hline II option $-33 \times 45$ & 2.61 & 1.5 & & 26.9 & 0.6 & & 10.3 & 35.9 \\
\hline III option $-33 \times 60$ & 2.85 & 1.9 & & 31.2 & 0.70 & & 11.5 & 51.8 \\
\hline $\begin{array}{l}L S D_{05}: \\
2018 \\
2019 \\
2020\end{array}$ & $\begin{array}{l}- \\
-\end{array}$ & $\begin{array}{l}- \\
-\end{array}$ & & $\begin{array}{l}- \\
-\end{array}$ & $\begin{array}{l}- \\
-\end{array}$ & & - & $\begin{array}{l}5.1 \\
7.4 \\
8.6\end{array}$ \\
\hline
\end{tabular}

The performed mathematical analysis showed that the ied from $0.78\left(1^{\text {st }}\right.$ stage $)$ to $1.22 \mathrm{~cm} /$ day $\left(3^{\text {rd }}\right.$ stage $)$. The difference in the productivity of root systems (on average experiment revealed the influence of the feeding area on per 1 plant) in the second and third variants, in compari- all parameters of Scutellaria baicalensis; it has been esson with the control, was obtained reliable, it significantly tablished that the larger the feeding area, the better the exceeds the value of $\mathrm{LSD}_{05}$.

\section{Discussion and Conclusion}

The analysis of the obtained results showed that under the conditions of the Middle Urals, Scutellaria baicalensis Georgi undergoes a full development cycle during the growing season: the transition to the generative stage was noted at the end of June, the flowering phase began from mid-July, and the fruiting phase - in the first decade of August. The Baikal skullcap adapts quite well to local natural and climatic conditions, as evidenced by such indicators as plant height and average daily growth. The maximum average daily gain was observed in the II and III decades of July, according to the variants it varplants are developed, the more leaves, flowers and fruits are formed. The highest productivity of aboveground biomass was obtained with a feeding area of $33 \times 60 \mathrm{~cm}$, on average per plant, it was $251.5 \mathrm{~g}$, which is $162.2 \mathrm{~g}$ $(181.6 \%)$ more than in the control. The yield per unit area reached $1257.4 \mathrm{~g} / \mathrm{m}^{2}$ - this is the maximum value of aboveground biomass obtained in the experiment.

The underground biomass of Scutellaria baicalensis is also closely dependent on the feeding area: it is well developed in the third variant $(33 \times 60 \mathrm{~cm})-$ $51.8 \mathrm{~g} /$ plant, which is $162.9 \%$ more than in the control variant $(33 \times 30 \mathrm{~cm})$ and $80.7 \%$ higher than in the second version $(33 \times 45 \mathrm{~cm})$.

\section{References}

1. Ilyina T. A. Lekarstvennye rasteniya: bol'shaya illyustrirovannaya entsiklopediya [Medicinal plants: A large illustrated encyclopedia]. Moscow: "E”, 2017. 304 p. (In Russian.)

2. Filippova I. Rynok rastitel'nykh sredstv: problemy, perspektivy, prioritety // Remedium. Zhurnal o rossiyskom rynke lekarstv i medicinskoiy tehnike. 2016. No. 7-8. Pp. 15-16. (In Russian.)

3. Abramchuk A. V. Biologicheskaya produktivnost' nadzemnoy biomassy shlemnika baykal'skogo (Scutellaria baicalensis Georgi) [Biological productivity of the above-ground biomass of the Scutellaria baicalensis Georgi] // Agrarnoe obrazovanie i nauka. 2019. No. 2. P. 11. (In Russian.)

4. Vse o lekarstvennykh rasteniyakh [All about medicinal plants]. Saint Petersburg: SZKEO, 2016. 192 p. (In Russian.)

5. Safonov N. N. Polnyy atlas lekarstvennykh rasteniy. Moscow: EKSMO, 2017. 312 p. (In Russian.)

6. Pavlova P. A., Egorova P. S. Introduktsionnoe ispytanie Scutellaria baicalensis Georgi (shlemnika baiykal'skogo) v Yakutskom botanicheskom sadu [Scutellaria baicalensis Georgi introduction test in the Yakutsk botanical garden] // Nauka i obrazovanie. 2015. No. 3. Pp. 89-98. (In Russian.)

7. Simonova N. V., Dorovskikh V. A. Lekarstvennye rasteniya Amurskoy oblasti: uchebnoe posobie [Medicinal plants of the Amur region: a tutorial]. Blagoveshchensk, 2016. 309 p. (In Russian.)

8. Shevchuk O. M, Logvinenko L. A. Osobennosti razvitiya i antioksidantnye svoystva Scutellaria baicalensis Georgi pri introduktsiy na Yuzhnyy bereg Kryma [Features of development and antioxidant properties of Scutellaria ba- 


\section{Agrarian Bulletin of the Urals No. 05 (208), 2021}

icalensis georgi during introduction to the Southern coast of Crimea] // Sbornik nauchnykh trudov Gosudarstvennogo Nikitskogo botanicheskogo sada. 2018. Pp. 128-134. (In Russian.)

9. Grebennikova O. A., Paliy A. E., Logvinenko L. A. Biologicheski aktivnye veshchestva Scutellaria baicalensis Georgi [Biologically active substances Scutellaria baicalensis Georgi] // Byulleten' Gosudarstvennogo Nikitskogo botanicheskogo sada. 2015. Vol. 117. Pp. 60-66. (In Russian.)

10. Abramchuk A. V. Produktivnost' podzemnoy biomassy shlemnika [Productivity of underground biomass of the Baikal skullcap (Scutellaria baicalensis Georgi)] // Agrarnoe obrazovanie i nauka. 2019. No. 1. P. 24. (In Russian.)

11. Insanu M., Rizaldy D., Silviani V., Fidrianny I. Chemical Compounds and Pharmacological Activities of Cucumis genus // Biointerface Research in Applied Chemistry. 2021. Vol. 12. Iss. 1. 2021. Pp. 1324-1334.

12. Khudonogova E. G., Rachenko M. A., Dubrovsky N. G., Popova O. A., Taisayev T. T. Stocks of raw materials of wild medicinal plants in the Western Baikal Region // AGRITECH IOP Conf. Series: Earth and Environmental Science. 2019. Vol. 315. Iss. 07. Article number 72002. DOI: 10.1088/1755-1315/315/7/072002.

13. Kukhareva L. V., Titok V. V., Popov E. G., Gil T. V. Baikal Shlemnik (Scutellaria baicalensis Georgi) - useful properties, biology, growth and development during introduction to Belarus // Problems of botany in Southern Siberia and Mongolia. 2018. No. 17. Pp. 485-487.

14. Darman G. F. Skullcap Baikal - Scutellaria baicalensis Georgia // Red Book of the Amur region: Rare and endangered species of animals, plants and fungi. Official publication. Blagoveshchensk, 2020. Pp. 285-286.

15. Karpukhin M. Yu., Abramchuk A. V. The problem of introduction of rare and endangered plants of the Middle Urals' flora // E3S Web of Conferences. Series: International Scientific and Practical Conference "From Inertia to Develop: Research and Innovation Support to Agriculture”, IDSISA 2020. Article number 03008.

\section{Authors' information:}

Anna V. Abramchuk ${ }^{1}$, candidate of biological sciences, associate professor, associate professor of the department of plant production and selection, ORCID 0000-0002-7908-4416, AuthorID 94812; +7953 005-68-44, fito41@mail.ru Mikhail Yu. Karpukhin ${ }^{1}$, candidate of agricultural sciences, associate professor, vice-rector for research and innovation, ORCID 0000-0002-8009-9121,AuthorID 339196; mkarpukhin@yandex.ru

Svetlana E. Saparklycheva ${ }^{1}$, candidate of agricultural sciences, associate professor, associate professor of the department of plant production and selection, ORCID 0000-0003-0463-7749, AuthorID 651975; +7 922 295-23-58, s.e.saparklycheva@mail.ru

Valentina V. Chulkova ${ }^{1}$, candidate of agricultural sciences, associate professor, associate professor, of the department of plant production and selection, ORCID 0000-0003-4757-9665, AuthorID 1061367, + 7908 916-40-75, vchulkova75@mail.ru

${ }^{1}$ Ural State Agrarian University, Ekaterinburg, Russia 